ARTICLE

Received 19 Dec 2016 | Accepted 19 Dec 2016 | Published 24 Jan 2017

DOI: $10.1057 /$ palcomms.2016.109

OPEN

\title{
Gender diversity on corporate boards: an empirical investigation of Italian listed companies
}

\author{
Silvia Solimene ${ }^{1}$, Daniela Coluccia ${ }^{1}$ and Stefano Fontana ${ }^{1}$
}

\begin{abstract}
In recent years, there has been a growing consensus that gender diversity could improve the economic and social performance of companies-although progress has been painfully slow. In Italy, Law n. 120/2011 has required that since 2012 the composition of corporate boards must comprise at least 1/5 women and, from 2015, 1/3 women. Here, our primary aim was to study the proportion and the progression of female directors on the boards of Italian companies over the period between 2009-2014, among a sample of 60 companies listed on the Milan Stock Exchange. We additionally studied the characteristics of the women on the companies' boards, in order to assemble a typical profile. To do this, we verified the boards' compositions, the number of female directors, women's power on the boards and their levels of education. Our results confirm that Italian law has produced significant effects on the composition of corporate boards. Moreover, we found that female directors are generally of Italian ethnic origin and have high levels of education, with a master's, and sometimes, post-master's degree. Furthermore, female directors are more likely to be professional figures with experience-the percentages of female directors with professional qualifications as well as the percentage of female directors on boards of other companies have consistently increased during the period mentioned. Our findings provide a descriptive analysis of female directors during the period between 2009-2014, thereby presenting a picture of gender equality in the Italian context. To our knowledge, this is the first study that has focused on examining gender equality among Italian-listed companies over such a long period. Future development of this research could examine in more depth the differences between male and female presence, behaviour and characteristics on boards, as well as how these issues affect the performance of firms. This article is published as part of a collection on the role of women in management and the workplace.
\end{abstract}

\footnotetext{
${ }^{1}$ University of Rome Sapienza, Rome, Italy Correspondence: (e-mail: silvia.solimene@uniroma1.it)
} 


\section{Introduction}

he issue of gender balance in corporate contexts has become a high-profile discussion point in recent years. Previous research on this issue can be categorised into three main groupings: women entrepreneurs, working women and women on corporate boards.

The role of women entrepreneurs. Until the 1970s, women in business had always played a marginal role (Cesaroni and Sentuti 2014). Since the 1980s, there has been a global rise in the number of women entrepreneurs, and, simultaneously, a rise in associated research. Previous research on female entrepreneurs focused its attention both on developed countries (Paoloni and Demartini, 2012; De Vita et al., 2014; Ahl and Nelson, 2015), and on emerging and undeveloped countries (Della-Giusta and Phillips, 2006; Welsh et al., 2014). These studies investigated the effects and the characteristics of female entrepreneurs (Danes et al., 2007; Xavier et al., 2012; Cesaroni and Sentuti, 2014; Paoloni and Dumay, 2015), their psychology and their motivation and the differences with male entrepreneurs (Ahl, 2006; Powell and Eddleston, 2008,2013; Ismail, 2014).

The presence of women in the corporate workforce. Research falling under this category has specifically analysed the effects produced in companies with a high level of female workforce. These studies have shown that the female workforce tends to exhibit greater attention to environmental behaviours (Hunter et al., 2004) and to climate change (Ciocirlan and Pettersson, 2012), and has more positive work-related attitudes toward the client organization (Selvarajan et al., 2015).

The presence of women on the boards of directors. Previous research in this area has focused on the diversity of board members, stating that a board with "different" members can make better decisions in regard to the different contributions that each director can give to business decisions. According to agency theory, the board has a very important role in solving agency problems and to ensuring a balance between the interests of shareholders and managers. To this end, diversity can improve the ability of the board: diversity on the board produces positive effects due to different knowledge, skills, experiences, ideas and behaviours. In accordance with stakeholder theory, a heterogeneous board can better satisfy the different requirements of different company stakeholders and is a stronger monitor of executive behaviour, as diversity brings varied viewpoints to board oversight (Carter et al., 2003; Arfken et al., 2004; Konrad et al., 2008; Adams and Funk, 2012).

In relation to this area, in this study we consider the level and the evolution of the presence of female directors on the boards of a sample of Italian-listed companies over the period between 2009-2014. We choose this period because of the issue of the Italian Law n. 120/2011 (known as Golfo-Mosca Law), which required that from 2012, in appointing a board women should comprise at least one-fifth and, from 2015, one-third of boards, up to 2022, when the Golfo-Mosca law will cease. As we will discuss further, this law produced an increase of the presence of women on boards. Italy took inspiration from other European countries. In 2003, Norway passed a law mandating at least 40 percent representation of each gender on the board of publicly listed companies. Many European countries have followed suit.

Most recently, Germany passed a law that requires publicly listed companies to have women occupy at least 30 percent of supervisory seats as of 2016. Overall, the introduction of quotas has supported a substantial rise in the share of women on the boards of Europe's largest publicly listed companies.
Furthermore, we analyse women's characteristics in order to identify a typical profile.

Our first contribution is to do a descriptive analysis of the presence of female directors from 2009-2014 among the sample of companies selected. We therefore provide a picture of the Italian situation in terms of gender equality. To our knowledge, this is the first study that analyses the situation of Italian-listed companies over such a long period. Previous research had studied gender diversity on boards before the Italian law that stipulated mandatory inclusion of women on corporate boards.

The second contribution of our study is to draw a women's profile to identify the characteristics that women need to enter the boards of listed companies.

Our research aims to address the following practical questions:

- Is women's participation only required by law or was it there before 2012?

- Do women on boards really have any power?

- Do female directors belong to major shareholders or are they external parties?

- What is a woman's educational profile?

To our knowledge, no previous research studies have assessed such questions in the Italian context.

\section{Gender diversity on boards}

Board diversity has been defined in different ways, but the literature has mainly investigated the effects of nationality and gender. In regard to gender diversity, despite a steady increase achieved in recent years, there is still scant representation of women on companies' boards. According to a survey carried out by the European Commission, in January 2012 the average board representation of female directors was just 13.7\% (European Commission, 2012). In order to increase the participation of women on a company's board, the European Commission launched the "Women on the Board Pledge for Europe", a call for all European companies willingness to sign a voluntary commitment to increase the percentage of female directors to $30 \%$ by 2015 and to $40 \%$ by 2020 . After this initiative, in 2011, some Member States enacted legislative measures aimed to realize equality between women and men on corporate boards. Despite these advances, women still hold very little power on corporate boards. In this regard, Zelechowski and Bilimoria (2004), after verifying the same characteristics between male and female among directors, found that very few women in corporate boards really had any power and were strategically well positioned. A similar conclusion was found by Seierstad and Opsahl (2011) who studied the effect of the Norwegian law, which required at least $40 \%$ representation of each sex for a public, limited company's board by 2008. They found an increase in the number of female directors without any advance in their power.

In regard to gender diversity, Terjesen et al. (2009) carried out a complete and thorough analysis of the existing literature on women serving on corporate boards. Comparing previous research, they identified three key areas: theoretical perspective, characteristics and the presence of women on corporate boards. In respect to the latter, previous research had investigated the effects of the presence of women on corporate boards. Singh et al. (2008) conducted a survey of a sample of the largest $100 \mathrm{UK}$ companies aimed to verify the differences between new male and new female directors nominated in the period between 20012004. Their results suggested that female directors-increasing during the period-were less likely to have top management experience in big companies and were more likely to have had previous career experience in public and non-profit sectors and on international boards. 
Adams and Ferreira (2009), in analysing a sample of firms by Standard and Poors, found that female directors are less likely to have attendance problems and also reduce the likelihood that their male counterparts have attendance problems. Furthermore, their results show that female directors are more likely to be assigned to monitoring-related committees, and are less likely to be assigned to a remuneration committee, compared to men.

Fernandez-Feijoo et al. (2014) studied the relationship between the level of CRS disclosure-measured through the KPMG report 2008-and companies with a board of at least three women. They tested that companies in countries with higher proportion of boards of directors with at least three women reported higher levels of CRS.

Carter et al. (2010) investigated firms in the S\&P 500 in the period 1998-2002 to verify the relationship between a firm's performance-measured by the ROA and Q Tobin-and the diversity on the board, in terms of women and race. Their results revealed a positive and significant relationship between the number of female directors and the ROA, while a non-significant relationship was found with the Q Tobin.

$* * *$

In relation to Italy specifically, there are still few studies about women on corporate boards. Drago et al. (2011) analysed Italianlisted companies and highlighted the effects on company value and performance of the interlocking women directors. They focused on all interlocking directors over the period between 20032010 to verify their gender and their role. They found a negative relationship between interlocking directors (including female interlocking directors) and the company's value and performance (measured by the equity value and the annual stock return).

Bianco et al. $(2011,2015)$ explored the board diversity on Italian listed companies, to verify its drivers and its effects. With reference to the characteristics of female directors, they verified whether female directors have a family connection with the controlling shareholder. At the end of 2009, the percentage was 47.3\% (Bianco et al., 2011); at the end of 2010 was 55\% (Bianco et al., 2015). Their results show that women linked to the shareholder family are more present in smaller companies, with concentrated ownership, while women unrelated to the shareholder family are present in bigger companies. With reference to director characteristics of Italian-listed companies in the period 2008-2010, they verified that there is less likelihood that women on the board are executive and independent directors. With reference to the effects of female directors, they tested whether the presence of female directors affects the board's behaviour. Using a regression model, they observed that a board with at least one woman had a lower number of meetings and that women performed worse than men in terms of meeting attendance.

\section{Research design}

As discussed in the context of Italy, in recent years there has been a slight increase in the number of women on company boards. To reverse this trend and to encourage the appointment of women directors, Law n. 120 was enacted in 2011.

In our research, we studied the level and the evolution of the presence of female directors on the boards of Italian companies between 2009-2014, to verify firstly whether women's participation on corporate boards was only required by law or whether it existed before 2012. Second, we considered whether companies in 2014 have just adopted a board structure in line with the obligations established by law for 2015. Furthermore, we have sought to identify women's characteristics. In particular, for each female director we verified:

- Education

- Professional qualification
- Nationality

- Age

- If the woman is an executive director

- If the woman is also a shareholder

- If the woman is also busy on other boards

To identify the number of female directors on corporate boards, we analysed the financial statement with specific reference to the section on corporate bodies of each company for each year. With a view to detect the characteristics of female directors, we related to public curriculum vitae published on company websites or elsewhere online. Since there are no relevant databases available, we had to conduct a manual survey.

\section{Sample selection}

The sample is composed of 60 Italian firms listed on the Milan Stock Exchange during the period between 2009-2014. Specifically, using the Datastream database, we excluded financial and insurance firms that apply different accounting rules. We sorted the non-financial companies according to their size, measured by the total asset. Companies listed in each year of the period between 2009-2014 were chosen in order to have a stable sample for each year. We excluded companies delisted before 2014 and those listed after 2009. Finally, we selected the 30 largest and the 30 smallest firms. We have chosen companies listed in each year of the period between 2009-2014 to ensure stability of the sample for each year.

Our sample of 60 companies listed can be classified into two sub-samples: the first one consisting of the largest 30 companies listed on the Milan Stock Exchange and the second consisting of the smallest 30 . Table 1 contains the companies within the sample divided in two subsamples.

\section{Results and discussion}

Descriptive statistics. In our analysis, we identified the number of female directors on each board and, among these, the number of female directors that have real power on the corporate board. To verify the power of female directors we chose to study the number of female directors with proxies, although, clearly, there are other strategies for identifying female directors' power.

Tables 2 and 3 contain the descriptive statistics of the two analysed variables: the number of female directors and the number of female directors with proxies.

As evidenced from the tables, in the period between 20092014, the number of female directors on the board ranges between 0 to 5 with a steady increase of the average from 0.65 in 2009 to 2.47 in 2014 . With reference to women with power, we note that the number ranges between 0 to 2 , with an increase of the average level from 0.17 in 2009 to 0.33 in 2014 . The median shows that only by the total number of female directors there has been an important increase; but for the number of female directors with proxies, the median is stable and equal to 0 on the whole period analysed.

Trends over the period between 2009-2014. As discussed, with the enforcement of law n. 120/2011, there was clear growth of the number of female directors in almost all companies within the sample, as evidenced by the following graphs. (Figs. 1 and 2).

As evidenced by the above graphs, before law n. 120/2011, many companies showed a lack of female directors. The blue, red and green lines are often equal to zero. The purple line starts to get up until the orange line that is the highest and shows that in 2014, just four companies did not have any women on their corporate board (Tenaris, Gas Plus, Fiera Milano and Pininfarina). 


\section{Table 1 | Sample selection}

Enel

Exor Ord

Eni

Fiat Chrysler

Telecom Italia

Atlantia

Finmeccanica

Snam

Saipem

Terna Rete Elettrica Naz

Tenaris

A2A

Italmobiliare

Luxottica

Italcementi Fabbriche Riunite

Hera

Pirelli

Mediaset

Iren

Acea

Impregilo

Astm

Cir Cie.Indi.Riun.

Sias

Prysmian

Buzzi Unicem Rsp

Danieli \&.C Rsp

Parmalat

Beni Stabili

Astaldi
Total assets at 31/12/2014

159.567 .000

145.593 .000

140.976 .000

96.963 .000

70.433 .000

32.359 .836

26.731 .000

24.906 .000

17.594 .000

15.059 .200

13.568 .969

10.010 .000

9.622 .951

9.406 .098

8.599 .245

8.364 .630

7.424 .475

7.107 .500

6.629 .401

6.615 .421

6.531 .241

6.135 .641

5.811 .893

5.790 .889

5.545 .000

5.108 .132

5.052 .414

4.582 .100

4.384 .493

4.068 .001 2nd Subsample name

Total assets at 31 December 2014

\begin{tabular}{|c|c|}
\hline Snai & 655.660 \\
\hline Fnm & 622.838 \\
\hline Reply & 601.660 \\
\hline Diasorin & 583.497 \\
\hline Datalogic & 559.652 \\
\hline Save-Aep.Di Vnz.Mrc.Polo & 555.541 \\
\hline Gas Plus & 555.202 \\
\hline La Doria & 553.658 \\
\hline Seat Pagine Gialle & 542.822 \\
\hline Prelios & 528.577 \\
\hline Yoox & 445.05 \\
\hline Aedes Ligure Lombarda & 435.20 \\
\hline Prima Industrie & 396.105 \\
\hline Zignago Vetro & 386.245 \\
\hline Biesse & 364.575 \\
\hline Reno De Medici & 363.296 \\
\hline Aeffe & 360.49 \\
\hline Emak & 340.032 \\
\hline Nice & 313.177 \\
\hline Cairo Communication & 308.398 \\
\hline Fiera Milano & 266.181 \\
\hline El En & 243.357 \\
\hline Basicnet & 198.349 \\
\hline Sabaf & 168.311 \\
\hline Bonifiche Ferraresi & 159.601 \\
\hline Cembre & 144.043 \\
\hline Pininfarina & 141.318 \\
\hline Valsoia & 82.37 \\
\hline Bastogi & 47.316 \\
\hline Molmed & 29.58 \\
\hline
\end{tabular}

Table 2 | Female directors on boards-descriptive statistics

\begin{tabular}{lllllll}
\multicolumn{7}{c}{ Female directors on boards } \\
\hline & 2009 & 2010 & 2011 & 2012 & 2013 & 2014 \\
\hline Min & 0 & 0 & 0 & 0 & 0 & 0 \\
Max & 4 & 4 & 3 & 4 & 5 & 5 \\
Mean & 0.65 & 0.68 & 0.80 & 1.15 & 1.82 & 2.47 \\
Median & 0.50 & 1.00 & 1.00 & 1.00 & 2.00 & 3.00 \\
\hline
\end{tabular}

Table 3 | Female directors with delegated powerdescriptive statistics

\begin{tabular}{|c|c|c|c|c|c|c|}
\hline \multicolumn{7}{|c|}{ Female directors with delegated power } \\
\hline & 2009 & 2010 & 2011 & 2012 & 2013 & 2014 \\
\hline Min & 0 & 0 & 0 & 0 & 0 & 0 \\
\hline Max & 1 & 1 & 1 & 1 & 2 & 2 \\
\hline Mean & 0.17 & 0.17 & 0.18 & 0.18 & 0.23 & 0.33 \\
\hline Median & 0 & 0 & 0 & 0 & 0 & 0 \\
\hline
\end{tabular}

Before the law, the involvement of women on corporate boards was minimal. Only in 2014, the situation is in line with the requirements for 2012, but it is still far from the provisions for 2015.

To verify the level of the power of female directors in the board, we estimated:

- The percentage of female directors on the board through the ratio between the total female directors and the total of directors on the board;

- The percentage of female directors with proxies through the ratio between the total number of female directors with delegated power and the total number of female directors of the 60 companies.

With reference to the percentage of female directors on boards, the results show a clear increase of this ratio since 2012, the first year of application of the new Italian law, but only in 2014 did the percentage reach $1 / 5$, as highlighted in Table 4 .

With reference to the executive female directors, as evidenced from the above table, despite the increase in the number of women with proxies (from 10 in 2009 to 20 in 2014), there is a steady reduction in the average rate $(25.64 \%$ in 2009 and $13.51 \%$ in 2014). It follows that the rate of increase in the number of women with delegated power is lower than that of women in the board.

From our results, it appears that law n. 120/2011 introduced a gender balance that is more formal than substantial.

Analysis of the female director "profile" over the period between 2009 and 2014. As discussed, we set out to provide a profile to identify the characteristics that women on boards possess. For this purpose, for each female director we verified the education, the professional qualification, the nationality, the age, whether the woman is also a shareholder, and whether the woman is on boards of other companies.

Over the period assessed, there were increases in the number of foreign female directors, the number of female directors that are themselves shareholders of the companies and the number of female directors also serving on boards of other companies. In relation to the education, in the period there was an improvement of the level of education, with an increase in the number of female directors with a master's degrees, post-master's degrees, PhDs, other qualifications (for example, for accountants, lawyers and so on) and the number of female directors who are also university 


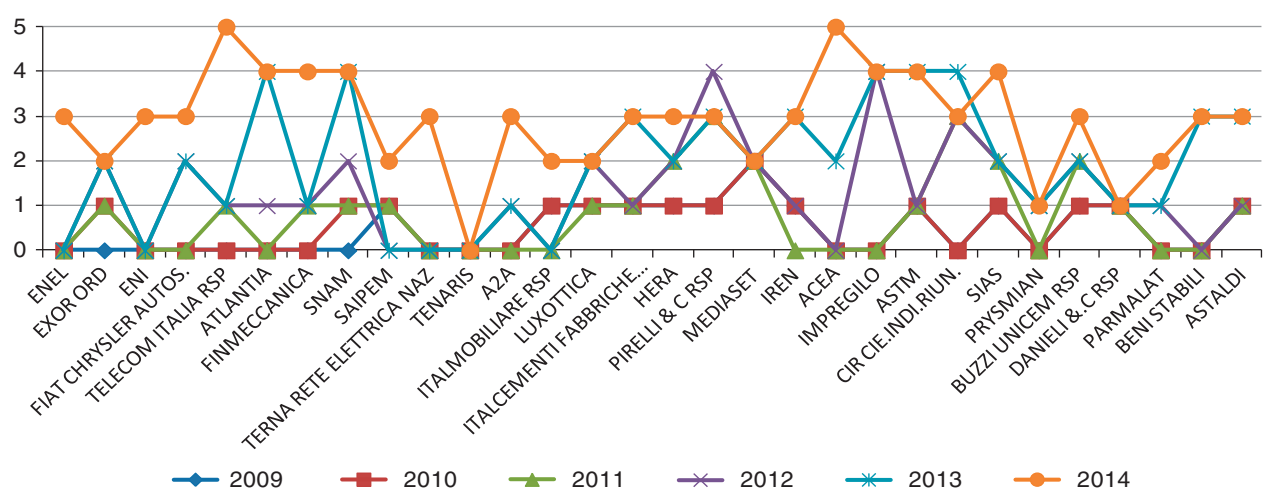

Figure 1 | The trend of female directors of the sample of the 30 biggest companies in the period between 2009 and 2014.

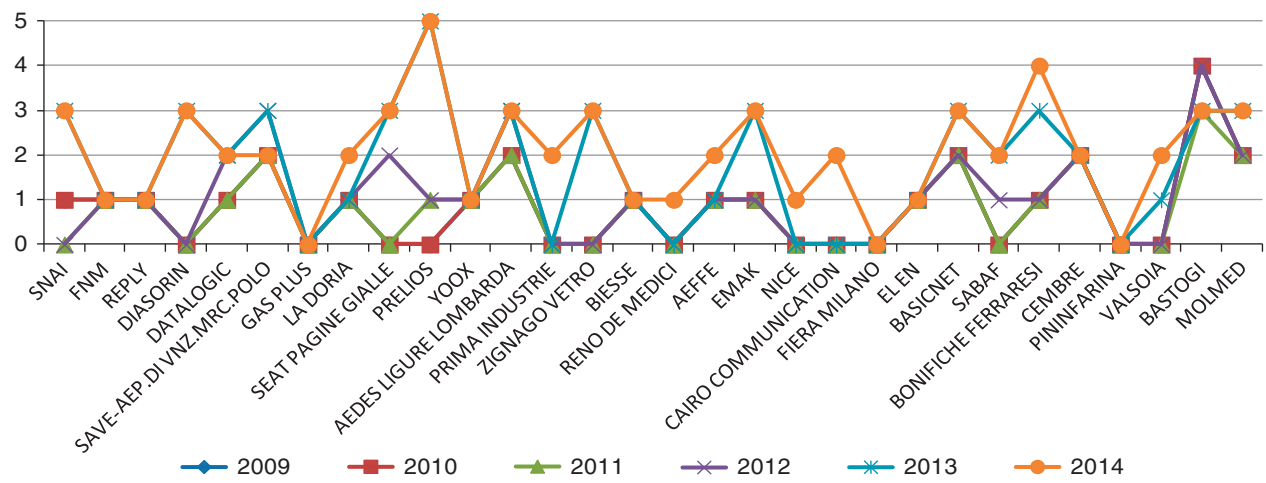

Figure 2 | The trend of female directors of the sample of the 30 smallest companies in the period between 2009 and 2014.

Table 4 | Trend and percentage of female directors on boards and of female directors with delegated power

Female directors

Average percentage of women on board

Female directors with delegated power

Percentage of executive female directors on total female directors

\begin{tabular}{llllll}
\multicolumn{1}{c}{2009} & \multicolumn{1}{c}{2010} & \multicolumn{1}{c}{2011} & \multicolumn{1}{c}{2012} & \multicolumn{1}{c}{2013} & \multicolumn{1}{c}{2014} \\
\hline 39 & 41 & 48 & 69 & 109 & 148 \\
$6.61 \%$ & $6.74 \%$ & $7.56 \%$ & $10.77 \%$ & $16,11 \%$ & $22.69 \%$ \\
10 & 10 & 11 & 11 & 14 & 20 \\
$25.64 \%$ & $24.39 \%$ & $22.92 \%$ & $15.94 \%$ & $12.84 \%$ & $13.51 \%$ \\
\hline
\end{tabular}

professors. The average age of female directors, after an increase in the period between 2009 and 2011, is constant at 51 .

To better understand the phenomena explained in Fig. 3 and Fig. 4, we estimated the percentage among the total number of female directors. As shown in Table 5 "female directors" in our sample are in more than $90 \%$ of cases Italian and in most cases, they are professional figures, not belonging to the families that control the company, and are also involved on other boards.

The analysis of the level of the education shows that the profile "female director" in our sample is a woman with master's degree and in limited cases with academic experiences and rarely with a $\mathrm{PhD}$. In most cases, "female directors" in our sample are professional figures, with post-master's degrees and other qualifications.

\section{Conclusions}

In recent years, there has been a growing consensus that gender diversity could improve the economic and the social performance of companies, but the progress has been painfully slow. In Italy, Law n. 120/2011 required that from 2012, boards should comprise at least $1 / 5$ and from $20151 / 3$ of women. Here our first aim was to study the level and the evolution of the presence of female directors on the boards of Italian-listed companies over the period between 2009 and 2014. The results confirm that the

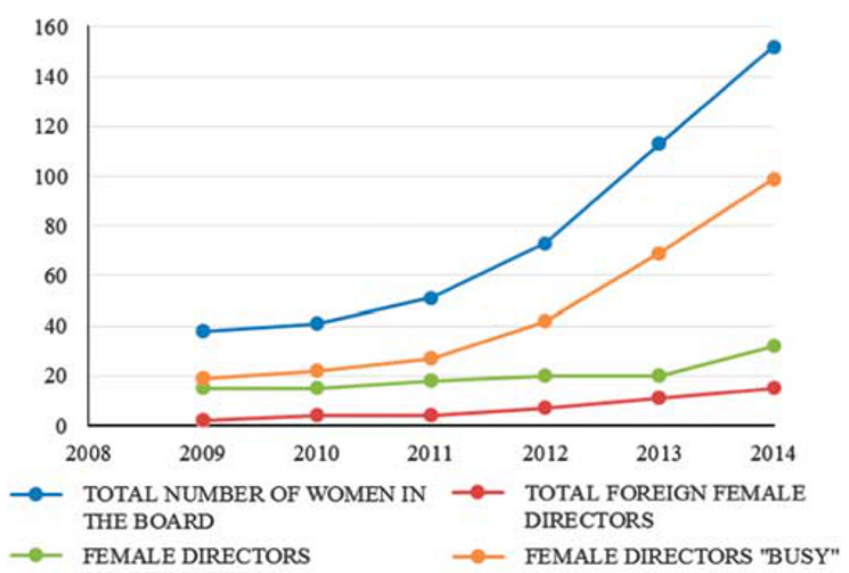

Figure 3 | The characteristics of female directors on boards in the period between 2009 and 2014.

new law has produced effects on the composition of corporate boards. In 2014, only four companies in our sample had not appointed women on the board at all (Tenaris, Gas Plus, Fiera Milano and Pininfarina). 
Table 5 | The characteristics of female directors on boards over the period 2009-2014

\begin{tabular}{lrrrrr} 
& 2009 & 2010 & \multicolumn{1}{c}{2011} & 2012 & \multicolumn{1}{c}{2013} \\
\hline Total foreign female directors & $5.26 \%$ & $9.76 \%$ & $7.84 \%$ & $9.59 \%$ & $9.73 \%$ \\
Total female directors shareholders & $39.47 \%$ & $36.59 \%$ & $35.29 \%$ & $27.40 \%$ & $17.70 \%$ \\
Total female directors "busy" & $50.00 \%$ & $53.66 \%$ & $52.94 \%$ & $57.53 \%$ & $61.06 \%$ \\
\hline
\end{tabular}

Table 6 | The education of female directors on boards over the period between 2009-2014

\begin{tabular}{|c|c|c|c|c|c|c|}
\hline & 2009 & 2010 & 2011 & 2012 & 2013 & 2014 \\
\hline Total female director with a master degree & $78.95 \%$ & $80.49 \%$ & $70.59 \%$ & $78.08 \%$ & $82.30 \%$ & $84.21 \%$ \\
\hline Total female directors with a post-master degree & $13.16 \%$ & $9.76 \%$ & $15.69 \%$ & $24.66 \%$ & $30.97 \%$ & $30.92 \%$ \\
\hline Total female directors with other qualifications & $34.21 \%$ & $36.59 \%$ & $31.37 \%$ & $35.62 \%$ & $44.25 \%$ & $49.34 \%$ \\
\hline Total female directors with PhD & $0.00 \%$ & $0.00 \%$ & $1.96 \%$ & $4.11 \%$ & $9.73 \%$ & $11.18 \%$ \\
\hline Total female directors academics & $5.26 \%$ & $4.88 \%$ & $11.76 \%$ & $13.70 \%$ & $18.58 \%$ & $23.03 \%$ \\
\hline
\end{tabular}

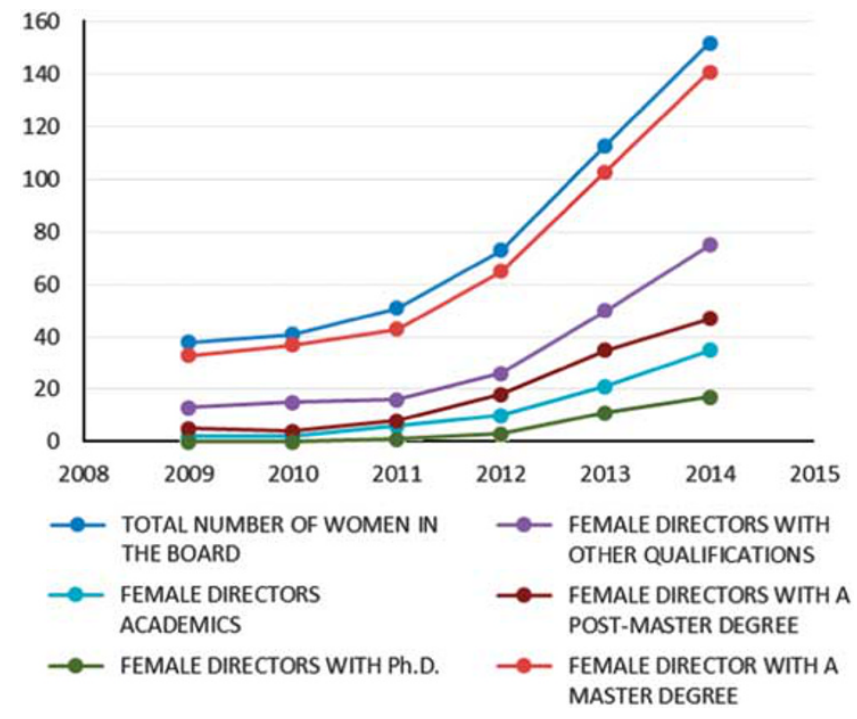

Figure 4 | The education of female directors on boards in the period between 2009-2014.

If the law has been effective in terms of the presence of women on boards, the same effects were not apparent with reference to the power of women directors. In fact, compared to a constant increase in the average number of female directors (from $6.61 \%$ in 2009 to $22.69 \%$ in 2014), the results show a decrease in the percentage of women with proxies (from $25.64 \%$ in 2009 to $13.51 \%$ in 2014). It follows that the law introduced a gender balance of more form than substance.

Our second aim was to study the characteristics of women on a company boards to identify a typical profile. Our results show that female directors are generally Italian and have a high level of education, with master's degrees and sometimes post-master's degrees. Most likely the high levels of education come from the fact that women are still a minority in the world of business and a demonstration of further qualifications and titles is needed to secure appointments to corporate boards. Furthermore, female directors are more likely professional figures, with experience (average age of 51 years), the percentage of female directors with professional qualifications has consistently increased over the period (from $34.21 \%$ in 2009 to $49.34 \%$ in 2014), and the percentage of female directors busy on boards of other companies (from $50 \%$ in 2009 to $65.13 \%$ in 2014). We also see that the number of female directors who are shareholders has undergone a constant decrease in the period. Instead of appointing women belonging to the shareholder's family, companies have preferred to appoint external female directors.

The increasing percentage of women engaged in other boards confirms the interlocking phenomenon in Italy. In this way, the vast majority of Italian listed companies are connected in a single network through a small minority of administrators.

Our study has some limitations: first, we have analysed just a sample of Italian-listed companies. In the future an analysis that involves all Italian-listed companies would clearly be useful. Second, to verify the power of female directors, we considered executive female directors. There are of course other ways to identify power on boards (for example, the role of President, of CEO, the appointment to important committees and so on). Finally, we gathered data only from publicly available information-as such, it is possible that some data could be incomplete.

Our article represents a first step toward developing an understanding of the levels of gender equality on the boards of Italian-listed companies. Future research could explore the differences between male and female presence, behaviour and characteristics on boards. Consequently, it would also be interesting to assess the effect of gender equality on the performance of firms. Furthermore, analysing whether the presence of women on boards could affect the CSR disclosure and CSR activity of the company, would be worthwhile.

\section{References}

Adams RB and Ferreira D (2009) Women in the Boardroom and their Impact on Governance and Performance. Journal of Financial Economics; 94 (2): 291-309.

Adams RB and Funk P (2012) Beyond the glass ceiling: does gender matter? Management Science; 5 (2): 219-235.

Ahl E (2006) Why research on women entrepreneurs needs new directions. Entrepreneurship: Theory \& Practice; 30 (5): 595-621.

Ahl $\mathrm{H}$ and Nelson $\mathrm{T}$ (2015) How policy positions women entrepreneurs: A comparative analysis of state discourse in Sweden and the United States. Journal of Business Venturing; 30 (2): 273-291.

Arfken DE, Bellar SL and Helms MM (2004) The ultimate glass ceiling revisited: The presence of women on corporate boards. Journal of Business Ethics; 50 (2) 177-186.

Bianco M, Ciavarella A and Signoretti R (2011) Women on boards in Italy. Consob Quaderni di finanza, n. 70.

Bianco M, Ciavarella A and Signoretti R (2015) Women on corporate boards in Italy: The role of family connections. Corporate Governance: An International Review; 23 (2): 129-144. 
Carter DA, Simkins BJ and Simpson WG (2003) Corporate governance, board diversity, and firm value. The Financial Review; 38 (1): 33-53.

Carter DA, D'Souza F, Simkins BJ and Simpson WG (2010) The gender and ethnic diversity of US boards and board committees and firm financial performance. Corporate Governance: An International Review; 18 (5): 396-414.

Cesaroni FM and Sentuti A (2014) Women and family businesses. When women are left only minor roles. The History of the Family; 19 (3): 358-379.

Ciocirlan C and Pettersson C (2012) Does workforce diversity matter in the fight against climate change? An analysis of fortune 500 companies. Corporate Social Responsibility and Environmental Management; 19 (1): 47-62.

Danes SM, Stafford K and Teik-Cheok Loy J (2007) Family business performance: The effects of gender and management. Journal of Business Research; 60 (10): 1058-1069.

Della-Giusta M and Phillips C (2006) Women entrepreneurs in the Gambia: challenges and opportunities. Journal of International Development; 18 (8): 1051-1064.

De Vita L, Mari M and Poggesi S (2014) Women entrepreneurs in and from developing countries: evidences from the literature. European Management Journal; 32 (3): 451-460.

Drago C, Millo F, Ricciuti R and Satella P (2011) The Role of Women in the Italian Network of Boards of Directors, 2003-2010. Working Paper Series Department of Economics University of Verona, n. 10.

European Commission (2012) Database on Gender Equality, Gender balance in decision-making positions, http://ec.europa.eu/justice/gender-equality/genderdecision-making/index_en.htm.

Fernandez-Feijoo B, Romero S and Ruiz-Blanco S (2014) Women on boards: Do they affect sustainability reporting? Corporate Social Responsibility and Environmental Management; 21 (6): 351-364.

Hunter LM, Hatch A and Johnson A (2004) Cross-national gender variation in environmental behaviors. Social Science Quarterly; 85 (3): 677-694.

Ismail VY (2014) The comparison of entrepreneurial competency in woman micro-, small-, and medium-scale entrepreneurs. Procedia-Social and Behavioral Sciences; 115, 175-187.

Konrad AM, Kramer V and Erkut S (2008) Critical mass: The impact of three or more women on corporate boards. Organizational Dynamics; 37 (2): 145-164.

Paoloni P and Demartini P (2012) The relational capital in female Smes. Journal of Academy of Business and Economics; 12 (1): 23-33.

Paoloni P and Dumay J (2015) The relational capital of micro-enterprises run by women: the start-up phase. VINE Journal of Information and Knowledge Management Systems; 45 (2): 172-197.

Powell GN and Eddleston KA (2008) The paradox of the contented female business owner. Journal of Vocational Behavior; 73 (1): 24-36.

Powell GN and Eddleston KA (2013) Linking family-to-business enrichment and support to entrepreneurial success: Do female and male entrepreneurs experience different outcomes. Journal of Business Venturing; 28 (2): $261-280$
Seierstad C and Opsahl T (2011) For the few not the many? The effects of affirmative action on presence, prominence, and social capital of women directors in Norway. Scandinavian Journal of Management; 27 (1): 44-54.

Selvarajan TT, Slattery J and Stringer DY (2015) Relationship between gender and work related attitudes: A study of temporary agency employees. Journal of Business Research; 68 (9): 1919-1927.

Singh V, Terjesen S and Vinnicombe S (2008) Newly appointed directors in newly appointed directors in the boardroom: How do women and men differ European Management Journal; 26 (1): 48-58.

Terjesen S, Sealy R and Singh V (2009) Women directors on corporate boards: A review and research agenda. Corporate Governance: An International Review; 17 (3): $320-337$.

Welsh DHB, Memili E, Kaciak E and Al Sadoon A (2014) Saudi women entrepreneurs: A growing economic segment. Journal of Business Research; 67 (5): 758-762.

Xavier SR, Ahmad SZ, Nor LM and Yusof M (2012) Women entrepreneurs: Making a change from employment to small and medium business ownership. Procedia Economics and Finance; 4, 321-334.

Zelechowski DD and Bilimoria D (2004) Characteristics of women and men corporate inside directors in the US. Corporate Governance: An International Review; 12 (3): 337-342.

\section{Data availability}

The datasets generated during and/or analysed during the current study are not publicly available. They are however available from the corresponding author on reasonable request.

\section{Additional information}

Competing interests: The authors declare no competing financial interests.

Reprints and permission information is available at http://www.palgrave-journals.com/ pal/authors/rights_and_permissions.html

How to cite this article: Solimene S et al (2017) Gender diversity on corporate boards: an empirical investigation of Italian listed companies. Palgrave Communications. 3:16109 doi: $10.1057 /$ palcomms.2016.109.

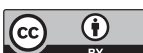

This work is licensed under a Creative Commons Attribution 4.0 International License. The images or other third party material in this article are included in the article's Creative Commons license, unless indicated otherwise in the credit line; if the material is not included under the Creative Commons license, users will need to obtain permission from the license holder to reproduce the material. To view a copy of this license, visit http://creativecommons.org/licenses/by/4.0/ 